\title{
高圧力下における塩化リチウム水溶液の粘性率†
}

\author{
中井武裕* 友 田好 昭* \\ 澤 村 精 治** 谷 口吉 弘**
}

\section{Viscosity of Aqueous Lithium Chloride Solution under High Pressure}

by

\author{
Takehiro NAKaI*, Yoshiaki Tomoda*, Seiji Sawamura ** \\ and Yoshihiro Taniguchi ${ }^{*}$
}

\begin{abstract}
The viscosity of aqueous lithium chloride $(\mathrm{LiCl})$ solution was measured at $0.1-375 \mathrm{MPa}$, at 278.2-318.2 $\mathrm{K}$, and 0.5 $4.0 \mathrm{~mol} \mathrm{~kg}^{-1}$. The Jones-Dole $B$ coefficients for $\mathrm{LiCl}$ in water were obtained from the concentration dependence of the viscosity, and were divided into each ionic contribution. In the studied ranges of pressure and temperature, the $B$ for $\mathrm{Li}^{+}$ion decreases monotonically with increasing pressure. However, the $B$ for $\mathrm{Cl}^{-}$ion increases with pressure up to 100-200 MPa. Pressure dependence of the $B$ for alkali metal ions $\left(\mathrm{Li}^{+}, \mathrm{Na}^{+}, \mathrm{K}^{+}\right.$and $\mathrm{Cs}^{+}$) were discussed supposing that the $B$ consists of three terms, that is, Einstein effect $\left(B_{\mathrm{E}}\right)$, dielectric friction effect for solvent $\left(B_{\mathrm{D}}\right)$, and structural effect of solvent $\left(B_{\mathrm{S}}\right)$.
\end{abstract}

Key words : High-pressure, Viscosity, Lithium chloride, Alkali metal ions, Jones-Dole $B$ coefficient

\section{1 は じめに}

希薄電解質溶液の粘性率の濃度依存性は Jones-Dole 式卢によってうまく再現される.

$$
\eta / \eta_{0}=1+A c^{1 / 2}+B c
$$

ここで $\eta$ と $\eta_{0}$ はそれぞれ溶液打よび純溶媒の粘性率, $c$ は溶液の容量モル濃度, $A$ と $B$ はその溶液に固有の定 数である. 特に係数 $B$ はイオン - 溶媒間相互作用を反映 していることから, イオン種, 溶媒, 温度等の違いによ る $B$ の挙動は, イオンの溶媒和の物理化学的解釈を行 う上で注目されてきた.2)

圧力は温度とならび水の構造や諸物性を変える重要な 環境因子であり, 特に室温以下の温度で, 水の性質の圧 力効果に異常な振る舞いが多く見い出されている. 例え ば, $277 \mathrm{~K}$ 付近の密度極大の高圧力下での消失, 圧力に対 する粘性率の極小, ${ }^{3)}$ 粘性流の活性化エネルギーの極小, NMR のスピンー格子緩和時間の極大 ${ }^{5)}$, 6)等である. こ れらに代表される水の特性が, $B$ 係数の圧力効果に如何 に反映されるかということを明瞭にすることが本研究の 目的である. $B$ 係数の圧力効果については，これまでに 我々が行なった一連の研究以外では報告例がない，アルカ リ金属塩化物水溶液の $B$ 係数では $\mathrm{NaCl},{ }^{7} \mathrm{KCl},{ }^{8), 9)}$ $\mathrm{CsCl}^{10), 11)}$ について報告してきたが，今回は $\mathrm{LiCl}$ を追加 し, $\mathrm{Li}^{+}$イオンの $B$ 係数の圧力依存性を他のアルカリ金 属イオン $\left(\mathrm{Na}^{+}, \mathrm{K}^{+}\right.$および $\left.\mathrm{Cs}^{+}\right)$の場合と比較する.

$$
2 \text { 実 験 方 法 }
$$

\section{$2 \cdot 1$ 試 料}

無水塩化リチウム（ナカライテスク社製特級試薬）は 使用前に $403 \mathrm{~K}$ で 3 日以上乾燥させたものを用いた. 水
は脱イオン後, 2 回蒸留したものを用いた。電解質水溶 液の濃度は $0.5,1.0,2.0,3.0,4.0 \mathrm{~mol} \mathrm{~kg}^{-1}$ に化学天秤 で調製した。その他試料調製の詳細は前報 ${ }^{7)}$ と同じで ある.

\section{$2 \cdot 2$ 粘性率測定}

常圧の粘性率はウベローデ型粘度計により，また高圧 力下の粘性率は当研究室で製作した転落球型粘度計 ${ }^{12)}$ に より測定した．転落球型粘度計による粘性率算出の基本 式は次に示す通りである.

$$
\eta=K\left(\rho_{\mathrm{b}}-\rho_{\mathrm{s}}\right) t,
$$

ここで $\rho_{\mathrm{b}}$ と $\rho_{\mathrm{s}}$ はそれぞれ粘度計内の球の密度および試 料溶液の密度, $t$ は試料溶液で満たされた試料管を傾斜 させた時に球が一定距離を通過する時間, また $K$ は各 温度, 圧力において水で校正したセ儿定数である. 粘度 計は $\pm 0.01 \mathrm{~K}$ 以内に温度制御した恒温槽に設置してあり， $t$ は $\pm 0.01 \mathrm{~s}$ の精度で読みとれる. 圧力は精度 $\pm 0.5 \mathrm{MPa}$ のフルスケール $700 \mathrm{MPa}$ ブルドン管式圧力ゲージ (Heise 社製) で読みとった。

\section{$2 \cdot 3$ 密度と圧縮ひずみ測定}

常圧の水溶液の密度 $\rho_{\mathrm{s}}{ }^{0}$ は, 内容積 $10 \mathrm{~cm}^{3}$ のオストワ ルド型ピクノメーターを用いて測定した. 高圧力下の水 溶液の密度 $\rho_{\mathrm{s}}$ は，圧縮ひずみ $k$ と $\rho_{\mathrm{s}}{ }^{0}$ によって式 (3) で 定義される。

$$
\rho_{\mathrm{s}}=\rho_{\mathrm{s}}{ }^{0} /(1-k),
$$

ここで $k$ は次式で定義される.

$$
k=\left(V^{0}-V^{\mathrm{p}}\right) / V^{0},
$$

ここで $V^{0}$ と $V^{\mathrm{p}}$ はそれぞれ常圧および高圧力下での試料の モル体積である. $\mathrm{LiCl}$ 水溶液の圧縮ひずみは前報 ${ }^{8)}$ と同 
様, 内容積 $7 \mathrm{~cm}^{3}$ の水銀トラップ式ピエゾメーターによ り測定した. 圧力は精度 $\pm 0.5 \mathrm{MPa}$ のフルスケール 400 $\mathrm{MPa}$ ブルドン管式圧力ゲージ（Heise 社製）で読みと り，温度は $\pm 0.1 \mathrm{~K}$ 以内に制御した。

\section{$3 \cdot 1$ 密度と圧縮ひずみ}

\section{3 結 果 と考察}

$\mathrm{LiCl}$ 水溶液の圧縮ひずみの值を Table I に示す。この 実験值は圧力 $p(\mathrm{MPa})$ の関数として Tait 式（式 (5)) に標準偏差 $5 \times 10^{-3}$ 以下でフィットできる.

$$
k=a \log [(b+p) /(b+0.1)]
$$

そのパラメータ $a, b$ を Table II に示す. 高圧力下の水 溶液の密度 $\rho_{s}$ は, Table IIの $a, b$ と式 (5) 加見積 もった $k$ を式 (3) に代入して得た。

\section{$\mathbf{3} \cdot \mathbf{2}$ 粘性率}

Table IIIに粘性率の值を示す．Fig. 1 には粘性率の圧

Table I. Compression $(k / \%)$ of aqueous lithium chloride solution.

\begin{tabular}{|c|c|c|c|c|c|}
\hline \multirow[b]{2}{*}{$p / \mathrm{MPa}$} & \multicolumn{5}{|c|}{$m / \mathrm{mol} \mathrm{kg}^{-1}$} \\
\hline & 0.5 & 1.0 & 2.0 & 3.0 & 4.0 \\
\hline & \multicolumn{5}{|c|}{$278.2 \mathrm{~K}$} \\
\hline 50 & 2.00 & 1.87 & 1.77 & 1.67 & 1.58 \\
\hline 100 & 3.73 & 3.55 & 3.35 & 3.15 & 2.98 \\
\hline 150 & 5.32 & 5.03 & 4.73 & 4.50 & 4.28 \\
\hline 200 & 6.74 & 6.44 & 6.03 & 5.74 & 5.46 \\
\hline 250 & 8.00 & 7.68 & 7.24 & 6.89 & 6.56 \\
\hline 300 & 9.16 & 8.84 & 8.35 & 7.98 & 7.61 \\
\hline \multirow[t]{2}{*}{350} & 10.25 & 9.91 & 9.40 & 9.00 & 8.62 \\
\hline & \multicolumn{5}{|c|}{$298.2 \mathrm{~K}$} \\
\hline 50 & 1.96 & 1.87 & 1.76 & 1.61 & 1.48 \\
\hline 100 & 3.54 & 3.42 & 3.29 & 3.05 & 2.85 \\
\hline 150 & 5.05 & 4.85 & 4.60 & 4.32 & 4.02 \\
\hline 200 & 6.44 & 6.12 & 5.82 & 5.53 & 5.21 \\
\hline 250 & 7.70 & 7.39 & 6.95 & 6.57 & 6.27 \\
\hline 300 & 8.80 & 8.50 & 8.05 & 7.62 & 7.32 \\
\hline \multirow[t]{2}{*}{350} & 9.86 & 9.53 & 9.04 & 8.62 & 8.30 \\
\hline & \multicolumn{5}{|c|}{$318.2 \mathrm{~K}$} \\
\hline 50 & 1.88 & 1.79 & 1.64 & 1.58 & 1.42 \\
\hline 100 & 3.44 & 3.32 & 3.14 & 2.93 & 2.77 \\
\hline 150 & 4.87 & 4.59 & 4.38 & 4.20 & 3.90 \\
\hline 200 & 6.04 & 5.85 & 5.56 & 5.28 & 5.01 \\
\hline 250 & 7.34 & 7.05 & 6.66 & 6.34 & 6.13 \\
\hline 300 & 8.47 & 8.13 & 7.73 & 7.40 & 7.15 \\
\hline 350 & 9.45 & 9.15 & 8.68 & 8.27 & 8.03 \\
\hline
\end{tabular}

Table II . Density at $0.1 \mathrm{MPa}$ and parameters of Tait's equation for aqueous lithium chloride solution.

\begin{tabular}{|c|c|c|c|c|c|}
\hline & \multicolumn{5}{|c|}{$m / \mathrm{mol} \mathrm{kg}^{-1}$} \\
\hline & 0.5 & 1.0 & 2.0 & 3.0 & 4.0 \\
\hline & & & $278.2 \mathrm{~K}$ & & \\
\hline \multirow{4}{*}{$\begin{array}{l}\rho_{\mathrm{s}}^{0} / \mathrm{g} \mathrm{cm}^{-3} \\
\mathrm{a} \\
b / \mathrm{MPa}\end{array}$} & 1.0120 & 1.0239 & 1.0455 & 1.0654 & 1.0843 \\
\hline & 0.3254 & 0.3500 & 0.3469 & 0.3544 & 0.3584 \\
\hline & 328.3 & 380.2 & 404.7 & 441.2 & 474.5 \\
\hline & & & $298.2 \mathrm{~K}$ & & \\
\hline \multirow{4}{*}{$\begin{array}{l}\rho_{\mathrm{s}}^{0} / \mathrm{g} \mathrm{cm}^{-3} \\
a \\
b / \mathrm{MPa}\end{array}$} & 1.0090 & 1.0201 & 1.0416 & 1.0615 & 1.0802 \\
\hline & 0.3264 & 0.3316 & 0.3075 & 0.3247 & 0.3887 \\
\hline & 347.9 & 373.2 & 363.1 & 417.2 & 552.4 \\
\hline & & & $318.2 \mathrm{~K}$ & & \\
\hline \multirow{3}{*}{$\begin{array}{l}\rho_{\mathrm{s}}{ }^{0} / \mathrm{g} \mathrm{cm}^{-3} \\
a \\
b / \mathrm{MPa}\end{array}$} & 1.0022 & 1.0134 & 1.0349 & 1.0549 & 1.0736 \\
\hline & 0.3156 & 0.3232 & 0.3126 & 0.3069 & 0.3836 \\
\hline & 352.7 & 382.4 & 391.9 & 407.0 & 563.3 \\
\hline
\end{tabular}

Table III. Viscosity of aqueous lithium chloride solution.

\begin{tabular}{|c|c|c|c|c|c|}
\hline \multirow[b]{2}{*}{$p / \mathrm{MPa}$} & \multicolumn{5}{|c|}{$m / \mathrm{mol} \mathrm{kg}^{-1}$} \\
\hline & 0.5 & 1.0 & 2.0 & 3.0 & 4.0 \\
\hline & \multicolumn{5}{|c|}{$278.2 \mathrm{~K}$} \\
\hline 0.1 & 1.617 & 1.721 & 1.944 & 2.187 & 2.451 \\
\hline 25 & 1.582 & 1.687 & 1.912 & 2.157 & 2.422 \\
\hline 50 & 1.559 & 1.665 & 1.891 & 2.136 & 2.400 \\
\hline 75 & 1.543 & 1.649 & 1.875 & 2.121 & 2.385 \\
\hline 100 & 1.534 & 1.640 & 1.866 & 2.112 & 2.377 \\
\hline 125 & 1.532 & 1.638 & 1.864 & 2.110 & 2.375 \\
\hline 150 & 1.535 & 1.641 & 1.867 & 2.113 & 2.378 \\
\hline 175 & 1.543 & 1.649 & 1.875 & 2.122 & 2.389 \\
\hline 200 & 1.556 & 1.661 & 1.889 & 2.137 & 2.406 \\
\hline 225 & 1.572 & 1.677 & 1.904 & 2.153 & 2.424 \\
\hline 250 & 1.590 & 1.694 & 1.922 & 2.173 & 2.448 \\
\hline 275 & 1.613 & 1.717 & 1.944 & 2.196 & 2.473 \\
\hline 300 & 1.638 & 1.741 & 1.968 & 2.221 & 2.501 \\
\hline 325 & 1.665 & 1.767 & 1.994 & 2.249 & 2.533 \\
\hline 350 & 1.694 & 1.795 & 2.019 & 2.276 & 2.566 \\
\hline \multirow[t]{2}{*}{375} & 1.726 & 1.824 & 2.048 & 2.307 & 2.602 \\
\hline & \multicolumn{5}{|c|}{$298.2 \mathrm{~K}$} \\
\hline 0.1 & 0.956 & 1.024 & 1.167 & 1.326 & 1.505 \\
\hline 25 & 0.949 & 1.015 & 1.160 & 1.323 & 1.503 \\
\hline 50 & 0.948 & 1.015 & 1.160 & 1.322 & 1.506 \\
\hline 75 & 0.949 & 1.015 & 1.161 & 1.326 & 1.508 \\
\hline 100 & 0.953 & 1.020 & 1.166 & 1.330 & 1.515 \\
\hline 125 & 0.958 & 1.025 & 1.172 & 1.338 & 1.523 \\
\hline 150 & 0.967 & 1.035 & 1.182 & 1.347 & 1.532 \\
\hline 175 & 0.976 & 1.044 & 1.192 & 1.359 & 1.544 \\
\hline 200 & 0.988 & 1.057 & 1.204 & 1.369 & 1.554 \\
\hline 225 & 1.000 & 1.067 & 1.215 & 1.382 & 1.568 \\
\hline 250 & 1.012 & 1.079 & 1.226 & 1.392 & .1 .579 \\
\hline 275 & 1.026 & 1.093 & 1.241 & 1.408 & 1.595 \\
\hline 300 & 1.043 & 1.111 & 1.258 & 1.424 & 1.609 \\
\hline 325 & 1.058 & 1.123 & 1.270 & 1.437 & 1.624 \\
\hline 350 & 1.074 & 1.139 & 1.285 & 1.452 & 1.640 \\
\hline \multirow[t]{2}{*}{375} & 1.093 & 1.159 & 1.304 & 1.469 & 1.655 \\
\hline & \multicolumn{5}{|c|}{$318.2 \mathrm{~K}$} \\
\hline 0.1 & 0.642 & 0.687 & 0.789 & 0.899 & 1.021 \\
\hline 25 & 0.644 & 0.691 & 0.791 & 0.901 & 1.019 \\
\hline 50 & 0.648 & 0.695 & 0.795 & 0.905 & 1.023 \\
\hline 75 & 0.655 & 0.701 & 0.802 & 0.911 & 1.028 \\
\hline 100 & 0.662 & 0.709 & 0.809 & 0.919 & 1.035 \\
\hline 125 & 0.669 & 0.716 & 0.819 & 0.930 & 1.044 \\
\hline 150 & 0.678 & 0.726 & 0.827 & 0.938 & 1.055 \\
\hline 175 & 0.686 & 0.734 & 0.838 & 0.950 & 1.067 \\
\hline 200 & 0.697 & 0.745 & 0.847 & 0.959 & 1.078 \\
\hline 225 & 0.705 & 0.754 & 0.858 & 0.971 & 1.090 \\
\hline 250 & 0.717 & 0.765 & 0.869 & 0.982 & 1.104 \\
\hline 275 & 0.726 & 0.776 & 0.880 & 0.995 & 1.119 \\
\hline 300 & 0.738 & 0.787 & 0.892 & 1.007 & 1.131 \\
\hline 325 & 0.749 & 0.799 & 0.905 & 1.020 & 1.144 \\
\hline 350 & 0.761 & 0.811 & 0.917 & 1.033 & 1.159 \\
\hline 375 & 0.773 & 0.823 & 0.930 & 1.047 & 1.173 \\
\hline
\end{tabular}

力依存性を示す，高圧力下の電解質水溶液の粘性率の データは，常圧のそれと比較して非常に少ないが, Lee らが $4.5 \mathrm{~mol} \mathrm{~kg}^{-1}$ の $\mathrm{LiCl}$ 重水溶液の粘性率を $303.2 \mathrm{~K}$ で $400 \mathrm{MPa}$ まで測定しており ${ }^{13)}$ 唯一我々の結果を比較で きる。この報告によると，粘性率は極小を持たず加圧と ともに増加しているので, 傾向は室温以上の我々の結果 と一致している.さらに常圧に対する高圧粘性率の比 $\eta$ $(350 \mathrm{MPa}) / \eta(0.1 \mathrm{MPa})$ を比較すると, Lee らのデータ では 1.11 であり, それと対応する我々のデータは Table IIIから補外すると $4.5 \mathrm{molkg}^{-1}{ }^{-1} 303.2 \mathrm{~K}$ で 1.10 となる. 重 水と軽水の違いがあるとは言え，似た挙動を示している. 


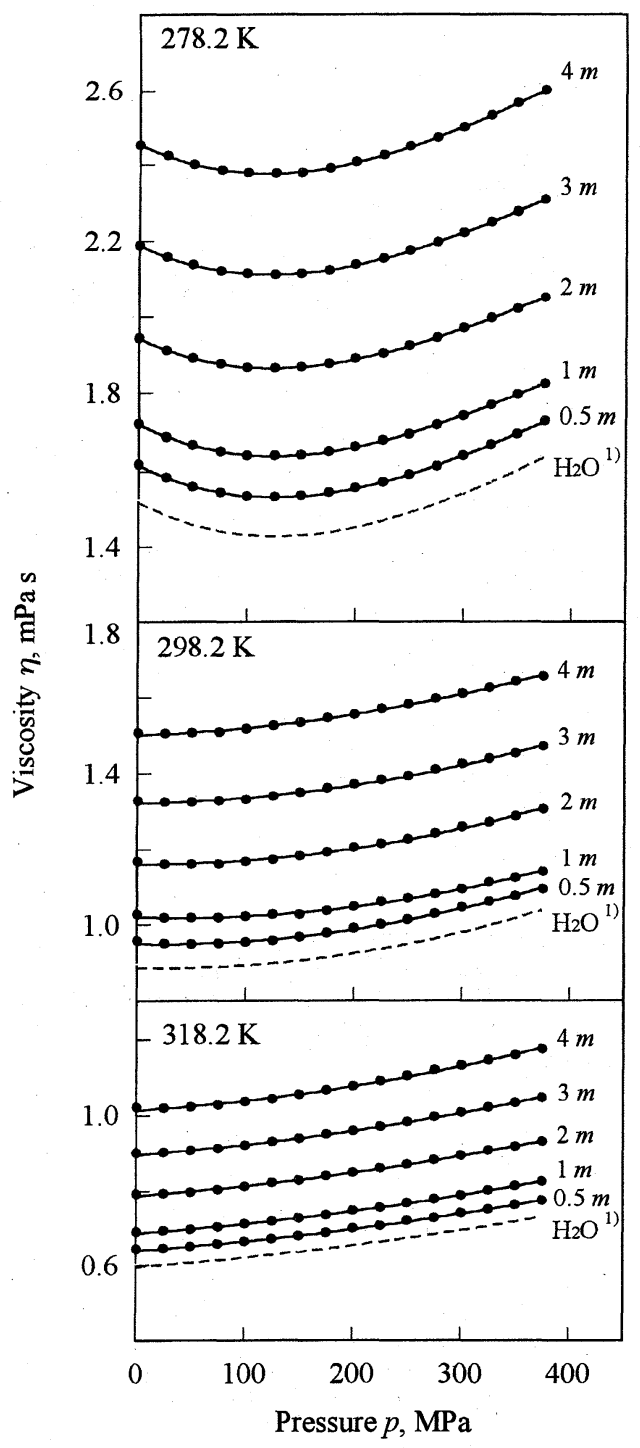

Fig. 1. Pressure dependence of the viscosity for aqueous lithium chloride solution. ${ }^{1)}$ Ref. 17.

\section{3-3 Jones-Dole $B$ 係数}

3・3・1 LiCl の B 係数 $B$ 係数の算出に式 (1) を適 用できるのは, 通常 $0.1 \mathrm{~mol} \mathrm{dm}{ }^{-3}$ 以下の濃度までであり, それ以上の高濃度領域では拡張型の Jones-Dole (式 (6) $)^{14)}$ を用いて解析する必要がある. 式 (6) から算出した $B$ 值 と式 (1) から算出した $B$ 值とは数 \% 以内で一致すること が知られる.

$$
\eta / \eta_{0}=1+A c^{1 / 2}+B c+D c^{2}
$$

式 (6) を変形すると式 (7) のようになる.

$$
\left(\eta / \eta_{0}-1-A c^{1 / 2}\right) / c=B+D c
$$

この式の $A$ は次に示す Falkenhagen と Vernon の理論式 ${ }^{16)}$ から見積もった。

$$
A=\frac{0.2577\left(\lambda_{+}^{0}+\lambda_{-}^{0}\right)}{\eta_{0}\left(\varepsilon_{0} T\right)^{1 / 2} \lambda_{+}^{0} \lambda_{-}^{0}}\left[1-0.6863\left(\frac{\lambda_{+}^{0}-\lambda_{-}^{0}}{\lambda_{+}^{0}+\lambda_{-}^{0}}\right)^{2}\right],(8)
$$

ここで $T$ は絶対温度， $\eta_{0}$ と $\varepsilon_{0}$ はそれぞれ溶媒の粘性率 ${ }^{17)}$ と誘電率 ${ }^{18)}, \lambda^{0}+$ と $\lambda^{0}$ - はイオンの極限モル電導率であ る. $\mathrm{Li}^{+}$と $\mathrm{Cl}^{-}$イオンの高圧力下での極限モル電導率の

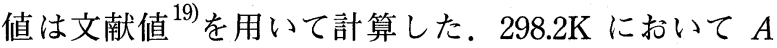

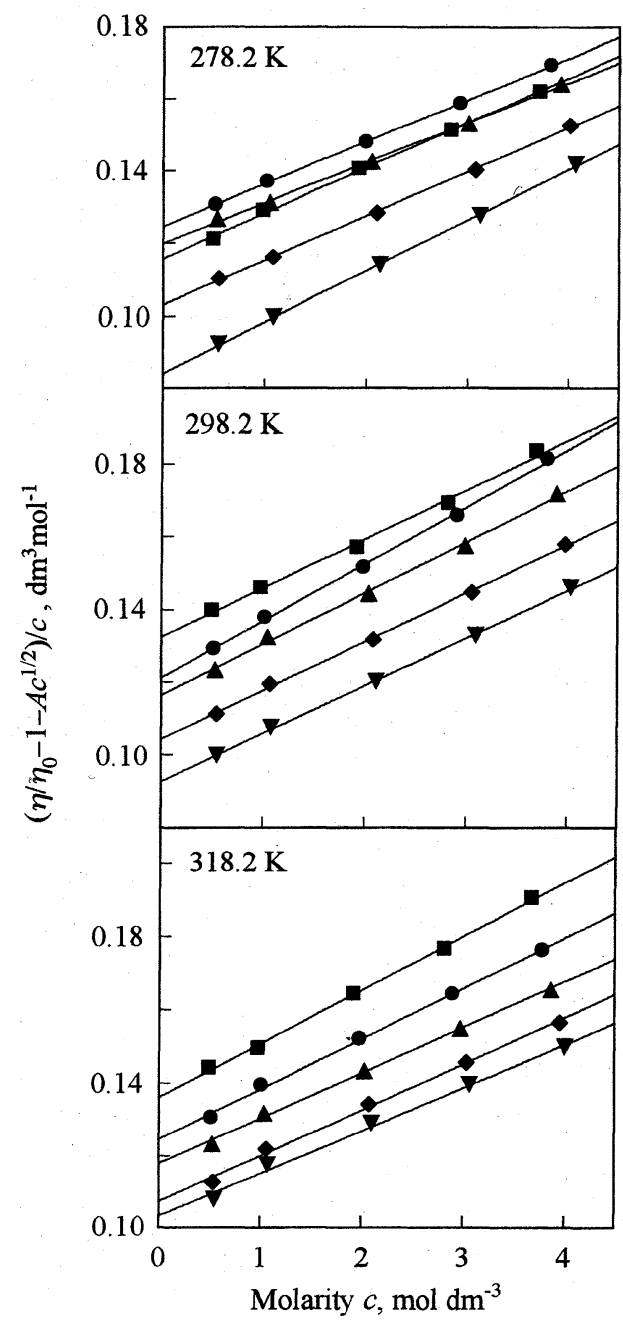

Fig. 2. $\left(\eta / \eta_{0}-1-A c^{1 / 2}\right) / c$ against $c$ for aqueous lithium chloride solution at $278.2 \mathrm{~K}, 298.2 \mathrm{~K}$ and $318.2 \mathrm{~K}$. 口, $0.1 \mathrm{MPa} ; \boldsymbol{\bigcirc}, 100 \mathrm{MPa} ; \boldsymbol{\Lambda}, 200 \mathrm{MPa} ; \diamond, 300$ $\mathrm{MPa} ; \boldsymbol{\nabla}, 375 \mathrm{MPa}$.

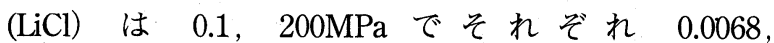
$0.0062 \mathrm{dm}^{3 / 2} \mathrm{~mol}^{-1 / 2}$ となる。また温度に対しては， 0.1MPa において 278.2，298.2，318.2K でそれぞれ $0.0068,0.0070,0.0071 \mathrm{dm}^{3 / 2} \mathrm{~mol}^{-1 / 2}$ と変化する. ${ }^{20)} こ れ$ らの值から $A$ 值は温度, 圧力に対して直線的に変化する とみなして, 各温度とも $375 \mathrm{MPa}$ まで補外して見積もっ た。この $A$ 值と粘性率から式 (7) の左辺を計算した. Fig. 2 は容量モル濃度 $c$ に対して式 (7) の左辺をプロット したものである. 容量モル濃度への変換は Table IIの密 度の值を用いて行った. 何れの圧力でも直線関係が得ら れており，切片から $B$ 值を見積もることができる. $0.1 \mathrm{MPa}$ に扎いて $B$ 值は $278.2,298.2,318.2 \mathrm{~K}$ でそれぞ れ $0.126,0.136,0.138 \mathrm{dm}^{3} \mathrm{~mol}^{-1}$ である. Outと Los の $B$ 值は $278.2 ， 298.2 ， 318.2 \mathrm{~K}$ でそれぞれ 0.1246 ， $0.1367,0.1416 \mathrm{dm}^{3} \mathrm{~mol}^{-1}$ であり ${ }^{20)}$ ，また $298.2 \mathrm{~K}$ では Laurence と Wolfenden が $0.139 \mathrm{dm}^{3} \mathrm{~mol}^{-1}$ 21) , Desnoyers と Perron が $0.138 \mathrm{dm}^{3} \mathrm{~mol}^{-1}{ }^{22)}$ と見積もって いる. 何れも我々の值と一致している. Fig. 3 には高圧 力下での $B$ 係数の挙動を示した. この図によると測定温 


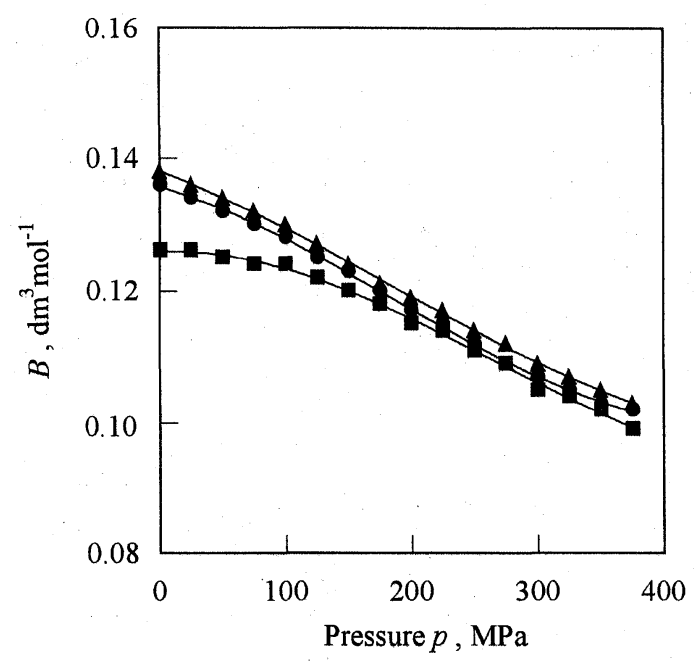

Fig. 3. Pressure dependence of $B$ for lithium chloride in water at $278.2 \mathrm{~K}(\mathbf{\square}), 298.2 \mathrm{~K}(\mathbf{O})$, and $318.2 \mathrm{~K}(\boldsymbol{\Delta})$.

度範囲において $B$ 係数は加圧とともに減少するのみであ り, $\mathrm{NaCl}, \mathrm{KCl}, \mathrm{CsCl}$ で観測された $100-200 \mathrm{MPa}$ 付近 での極大は見られない. ただし $278.2 \mathrm{~K} て ゙ は ~ 0.1-100 \mathrm{MPa}$ の範囲で上に凸の曲線になっており，さらに低温になる と極大を生じるかもしれない．また Fig. 3 の三本の等温 曲線は加圧とともに収束し, $100 \mathrm{MPa}$ 以上でほぼ一本の 線になっている.

電解質の $B$ 係数は, 個々のイオンの寄与の和 [B $\left.(\mathrm{MX})=\mathrm{B}\left(\mathrm{M}^{+}\right)+\mathrm{B}\left(\mathrm{X}^{-}\right)\right]$として表されることが知られて いる.しかしながら, 実験的には直接個々のイオンの $B$ 係数を求めることができないため, これまでいくつかの イオン分割法が提案されてきた。例えば Kaminsky は $B$ $\left(\mathrm{K}^{+}\right)=B\left(\mathrm{Cl}^{-23)}\right.$ を, Nightingale は $B\left(\mathrm{Rb}^{+}\right)=B\left(\mathrm{Br}^{-}\right)^{24)}$ を基準とした分割法を提案しているが，それぞれに一長 一短がある. 本研究では便宜上 Kaminsky の方法を採用 し，これが高圧力下でも成り立つとして解析した。笛の 結果を Fig. 4 に示す. $\mathrm{Li}^{+}$イオンの $B$ は何れの温度でも 加圧とともに減少するのに対し， $\mathrm{Cl}^{-}$イオンでは加圧と ともに最初増加した後, 極大を経て減少する. また圧力 一定の下での温度依存性に着目すると $\mathrm{Li}^{+}$は温度ととも に減少し，一方 $\mathrm{Cl}^{-}$では $B$ は温度とともに増加する. $B$ $\left(\mathrm{Li}^{+}\right)$と $B(\mathrm{Cl})$ の挙動は圧力依存性のみならず温度依 存性においても異なる挙動を示す。

より詳細に $B$ 係数の解釈をするために Kalugin らは $B$ を三つの寄与, すなわち Einstein 効果 $\left(B_{\mathrm{E}}\right)$, 配向効果 $\left(B_{\mathrm{D}}\right)$ ，構造的効果 $\left(B_{\mathrm{S}}\right)$ に分類している. $\left.{ }^{25}\right)$ これと類似の概 念はStokesとMillsによっても提案されている. ${ }^{26)}$ Einstein 効果は溶質のサイズや形に起因し， $B$ に正の寄 与をする。ここで言う配向効果は誘電摩擦効果に相当す る. 誘電摩擦はイオン周囲の溶媒双極子の誘電緩和の遅 れから生じる摩擦で, その影響はイオンの表面電荷密度 とともに大きくなる。この効果も $B$ に正の寄与をする. 構造効果は溶媒の構造形成, 構造破壞効果のことである. この構造形成効果と構造破壊効果は，それぞれ $B$ に正

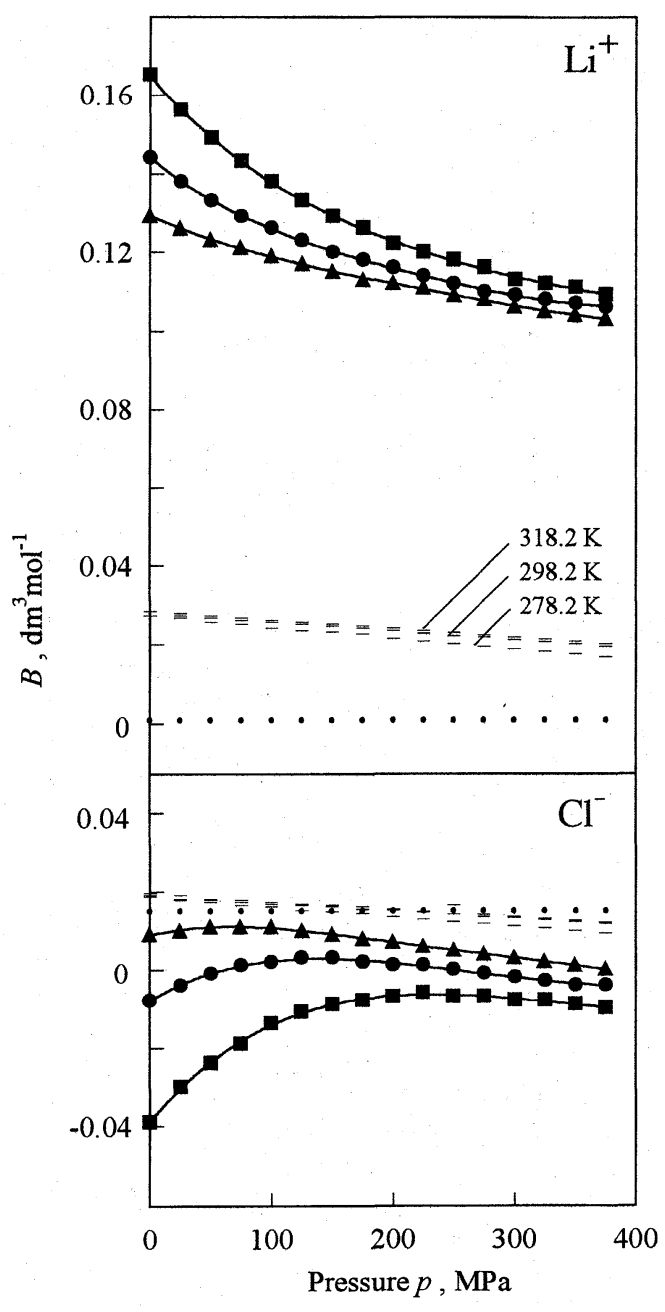

Fig. 4. Pressure dependence of $B$ for $\mathrm{Li}^{+}$and $\mathrm{Cl}^{-}$in water at $278.2 \mathrm{~K}(\boldsymbol{\square}), 298.2 \mathrm{~K}(\boldsymbol{\bullet})$, and $318.2 \mathrm{~K}(\mathbf{\Delta})$. ,$-- B_{\mathrm{D}} ; \cdots, B_{\mathrm{E}}$.

と負の寄与をする， $B$ はこれらの因子の和として次のよ うに書き表すことができる。

$$
B=B_{\mathrm{E}}+B_{\mathrm{D}}+B_{\mathrm{S}}
$$

よく知られているように $B_{\mathrm{E}}$ は式 (10) によって表され る。 $B_{\mathrm{D}}$ の寄与は伊吹と中原によって, HubbardOnsager の電気流体力学方程式から式 (11) のように導か れている. ${ }^{27)}$

$$
\begin{gathered}
B_{\mathrm{E}}=\frac{4 \pi R^{3}}{3} \frac{N}{1000}, \\
B_{\mathrm{D}}=R_{\mathrm{HO}}^{3} \frac{N}{1000} \exp \left(2.631+\sum_{j=1}^{4} a_{j}\left[\frac{R}{R_{\mathrm{HO}}}\right]^{j}\right),
\end{gathered}
$$

ここで $N$ はアボガドロ数, $a_{j}$ は展開係数 ${ }^{27)} R$ は結晶イオ ン半径, ${ }^{28}$ そして $R_{\mathrm{HO}}$ は溶媒パラメータで, HubbardOnsager 理論の中で次のように定義される. ${ }^{29), 30)}$

$$
R_{\mathrm{HO}}=\left(\frac{e^{2}\left(\varepsilon_{0}-\varepsilon_{\infty}\right) \tau_{\mathrm{D}}}{16 \pi \eta \varepsilon_{0}^{2}}\right)^{1 / 4}
$$

ここで $\tau_{D}$ は溶媒の誘電緩和時間, ${ }^{31)} \varepsilon_{\infty}$ は溶媒の高周波 誘電率 ${ }^{32)}$ である. 式 (10) ( (12) から, $\mathrm{Li}^{+}$と $\mathrm{Cl}^{-}$イオンの $B_{\mathrm{E}}$ と $B_{\mathrm{D}}$ の寄与をそれぞれ見積もって Fig. 4 に示した. 


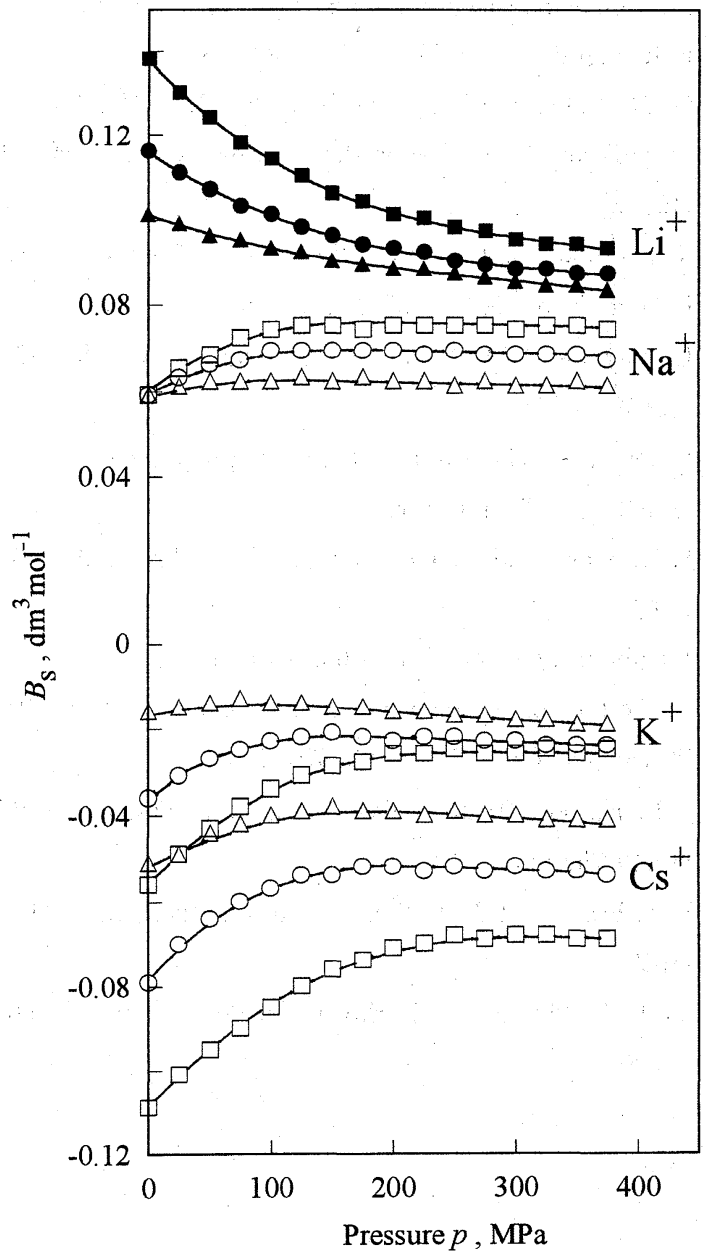

Fig. 5. Pressure dependence of $B_{S}$ for alkali metal ions in water at $283.2 \mathrm{~K}(\square), 298.2 \mathrm{~K}(\bigcirc)$, and $323.2 \mathrm{~K}$ $(\triangle) .(\square: 278.2 \mathrm{~K}, \boldsymbol{\square}: 298.2 \mathrm{~K}$, and $\boldsymbol{\Delta}: 318.2 \mathrm{~K}$ for $\mathrm{Li}^{+}$).

$B_{\mathrm{E}}$ は $R$ が温度, 圧力に依存しないとして見積もっている. $B_{\mathrm{D}}$ は加圧とともに減少している。常圧から200MPaまで の $\mathrm{Li}^{+}$イオンの $B$ の急激な減少や $\mathrm{Cl}^{-}$イオンの $B$ の急激 な増加は, 明らかにこれら $B_{\mathrm{E}}$ や $B_{\mathrm{D}}$ からの寄与によるも のでないことがわかり, 式 (9) の $B_{\mathrm{S}}$ の寄与によるものと 示唆される。

$3 \cdot 3 \cdot 2$ アルカリ金属イオンの B 係数の比較 Fig. 5 には式 (9) を用いて見積もった $\mathrm{Li}^{+}$イオンの $B_{\mathrm{S}}$ の挙動を 示す. また比較のため $\mathrm{Na}^{+}, \mathrm{K}^{+}(=\mathrm{Cl})$ および $\mathrm{Cs}^{+}$イオン の結果もあわせて示した， $B_{\mathrm{S}}$ の圧力依存性に対するイ オン間の相違は $200 \mathrm{MPa}$ 以下の低圧側において見られ， 圧力係数は $\mathrm{Li}^{+}, \mathrm{Na}^{+}, \mathrm{K}^{+}, \mathrm{Cs}^{+}$のイオン半径の順に負か ら正へと大きくなっている. 従来から $B$ 係数のイオン種 による正負の違いは Frank と Wen が提案したイオンの水

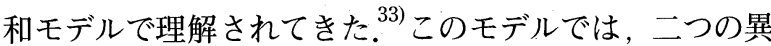
なった水からなる二重の水和層を想定している．イオン に接した内側の領域には，イオンに強く配向した秩序構 造の水和層があり，その外側には配向性がバルク水以上 に乱れた無秩序な水和層が存在する，構造形成，あるい は構造破壊効果の強さは，この二つの水和層の相対的な
大きさによってきまる。このモデルによると，イオン半 径が小さいほど, クーロン力にようて前者の水和層の寄 与（構造形成）が大きくなるので， $B$ 值は大きくなる. 逆にイオン半径が大きくなるにしたがって，クーロン力 が弱くなり, 後者の寄与 (構造破壊) が相対的に強くな る.その結果 $\mathrm{Li}^{+}$.イオンのような小さなイオンの $B$ 係数 は正で, $\mathrm{Cs}^{+}$イオンのような大きなイオンの $B$ 係数は負 となる.この. Frank-Wen の水和モデルに基づいて， $B$ 係数の圧力依存性を考察してみる。 $\mathrm{Cs}^{+}$イオンでは $(\partial B \mathrm{~s} / \partial p)>0$ となるが, これは加圧により水の構造性が 弱められ, バルク水自体が無秩序な水和層のような構造 性に近づき, $\mathrm{Cs}^{+}$イオンの構造破壊効果が相対的に弱ま るためと理解できる（無秩序層の水は圧力によって変化 しにくいとみなしている). Reddy と Berkowitzの 268K で

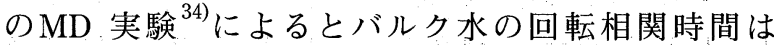
$200 \mathrm{MPa}$ の加圧で $13 \%$ 低下しているのに対し, $\mathrm{Cs}^{+}$イオ ンの水和水は $3 \%$ しか低下しない. このことは先に述べ た $B$ 值の相対的増加を裏づけるものである. 一方 $\mathrm{Li}^{+}$イ オンの場合も $\mathrm{Cs}^{+}$イオンと同様，バルク水破壊による $B$ 係数増大の寄与はあると考えられるが， $(\partial B \mathrm{~s} / \partial p)<0$ と なることから， $B$ 係数減少の寄与の方がより大きいと考 えられる．このことから $\mathrm{Li}^{+}$イオンでは，加庄によって バルク水とともに秩序性の高い水和水の構造もいくらか こわされていると考えられる。このように二つの水和層 の相反する寄与が競合し， $B \mathrm{~S}$ の圧力依存性に反映され ていると理解できる。100-200MPa までの低圧側で $B_{S}$ の圧力係数が, イオン半径の順に負から正へと変化して いるのもそのためである.

本研究によって，アルカリ金属イオンの $B$ 係数の圧力 依存性が，水和水やバルク水の破壊効果と，連続媒体と しての誘電摩擦の減少の効果とを反映していること，そ して水の構造性が高い低圧側においては，前者の効果が より支配的であることを示唆する結果が得られた.

\section{参 考 文 献}

1) G. Jones and M. Dole, J. Am. Chem. Soc., 51, 2950 (1929).

2) R. W. Gurney, "Ionic Processes in Solution", Chap. 9 (1962) McGraw-Hill.

3 ) K. E. Bett and J. B. Cappi, Nature, 207, 620 (1965).

4 ) R. A. Horne and D. S. Johnson, J. Phys. Chem., 70, 2182 (1966).

5 ) J. Jonas, T. DeFeries and D. J. Wiblbur, J. Chem. Phys., 65, 582. (1976)

6 ) T. DeFeries and J. Jonas, J. Chem. Phys., 66, 896 (1977).

7) S. Sawamura, Y. Yoshimura, K. Kitamura and Y. Taniguchi, J. Phys. Chem., 96, 5526 (1992).

8）中井武裕, 澤村精治, 谷口吉弘, 材料, 45，280（1996).

9) T. Nakai, S. Sawamura, Y. Taniguchi and T. Kuboyama, Mater. Sci. Res. Int., 3, 204 (1997).

10) T. Nakai, S. Sawamura and Y. Taniguchi, J. Mol. Liq., 65/66, 365 (1995).

11) T. Nakai, S. Sawamura, Y. Taniguchi and Y. Yamaura, 
Mater. Sci. Res. Int., 2, 143 (1996).

12) S. Sawamura, N. Takeuchi, K. Kitamura and Y. Taniguchi, Rev. Sci. Instrum., 61 871, (1990).

13) Y. K. Lee, J. H. Campbell and J. Jonas, J. Chem. Phys., 60, 3537 (1974).

14) G. Jones and S. K. Talley, J. Am. Chem. Soc., 55, 624 (1933).

15) G. Jones and H. J. Fornwalt, J. Am. Chem. Soc., 58, 619 (1936).

16) H. Falkenhagen and E. L. Vernon, Phil. Mag., 14, 537 (1932).

17) International Association for the Properties of Steam "The IAPS Formulation 1985 for the Viscosity of Ordinary Water Substance" (1985).

18) K. R. Srinivasan and R. L. Kay, J. Chem. Phys., 60, 3645 (1974).

19) M. Ueno, N. Tsuchihashi, K. Yoshida and K. Ibuki, J. Chem. Phys., 105, 3662 (1996).

20) D. J. Out and J. M. Los, J. Sol. Chem., 9, 19 (1980).

21) V. D. Laurence and J. H. Wolfenden, J. Chem. Soc., 1144 (1934).

22) J. E. Desnoyers and G. Perron, J. Sol. Chem., 1, 199 (1972).
23) M. Kaminsky, Discuss. Faraday Soc., 24, 171 (1957).

24) E. R. Nightingale, J. Phys. Chem., 63, 1381 (1959).

25) O. N. Kalugin, M. A. Gorobetz, R. M. N. Jalah, I. N. Vjunnik and Y. N. Zavgorodnij, Z. Phys. Chem., 199, 145 (1997).

26) R. H. Stokes and R. Mills, "Viscosity of Electrolytes and Related Properties" (1965) Pergamon.

27) K. Ibuki and M. Nakahara., J. Chem. Phys., 85, 7312 (1986).

28) L. Pauling, "The Nature of the Chemical Bond", p. 514 (1960) Cornell University.

29) J. Hubbard and L. Onsager, J. Chem. Phys., 67, 4850 (1977).

30) J. Hubbard, J. Chem. Phys., 68, 1649 (1978).

31) R. Pottel, E. Asselborn, R. Eck and V. Tresp, Ber. Bunsenges. Phys. Chem., 93, 676 (1989).

32) J. B. Hasted, "Water", Vol. 1 (ed. by F. Franks), p. 277 (1972) Plenum.

33) H. S. Frank and W. Y. Wen, Discuss. Faraday Soc., 24, 33 (1957).

34) M. R. Reddy and M. Berkowitz, J. Sol. Chem., 17, 1183 (1988). 